Insight Microbiology 3 (1): 9-14, 2013

ISSN 2041-0387 / DOI: 10.5567/IMICRO-IK.2013.9.14

(C) 2013 Insight Knowledge, UK

\title{
Inoculation of Glomus sp. Fungi and Pseudomonas sp. A Tool for Bioremediation of Cadmium Contaminated Soil
}

\author{
${ }^{1}$ Sivasankari Devi. T, ${ }^{2} \mathrm{M}$. Gomathy and ${ }^{3} \mathrm{~K} . \mathrm{R}$. Narayanan \\ ${ }^{1}$ Department of Agricultural Microbiology, UAS, GKVK, Bangalore-65, India \\ ${ }^{2}$ Departmentt of Agricultural Microbiology, Maize Research Station (MRS), Vagarai, Tamil Nadu, India \\ ${ }^{3}$ Department of Agricultural Microbiology, TNAU, Coimbatore-3, India
}

\begin{abstract}
Objective: Microbes are ubiquitous in nature, exploring them for cleanup the environment shows significant importance in bioremediation of heavy metals. Effects of dual inoculation of AM fungi with bacteria Pseudomonas on accumulation of $\mathrm{Cd}$ (II) in maize plants were studied at different levels $(0,75$ and $125 \mathrm{ppm})$ of $\mathrm{Cd}$ (II) and at different stages of plant growth (30 DAS, 60 DAS and at harvest). Materials and Methods: Cadmium tolerant Arbuscular Mycorrhizal (AM) fungi Glomus sp. $\left(\mathrm{AM}_{1}\right)$ and bacteria Pseudomonas sp. $\left(\mathrm{PS}_{1}\right)$ were used along with the standard cultures. Both fungal and bacterial species were isolated from the soil polluted with high concentration of cadmium in Coimbatore district of Tamil Nadu. Glomus mosseae (AMs) and Pseudomonas putida (PSs) were the standard cultures used in the study for comparative evaluation. Results: Dual inoculation gives the highest root colonization percentage, AM spore count, population of Pseudomonas in the rhizosphere. In addition, the plant biometric characteristics were also stimulated by dual inoculation. Inoculation of Glomus sp. $\left(\mathrm{AM}_{1}\right)$ with Pseudomonas sp. $\left(\mathrm{PS}_{1}\right)\left(\mathrm{T}_{6}\right)$ showed highest percentage of root colonization (92\%) at $125 \mathrm{ppm}$ of $\mathrm{Cd}$ on both 30 and $60 \mathrm{DAS}$ over control $\left(\mathrm{T}_{1}\right)$. Same treatment had shown increased dry biomass of $23.75\left(\mathrm{~g} \mathrm{pL}^{-1}\right)$ and it is on par with $\mathrm{T}_{8}$. The treatment $\mathrm{T}_{8}\left(\right.$ G. mosseae $\left(\mathrm{AM}_{\mathrm{S}}\right)$ with Pseudomonas sp. $\left.\left(\mathrm{PS}_{1}\right)\right)$ had accumulated high level of $\mathrm{Cd}$ in root $\left(3.1856 \mathrm{mg} \mathrm{g}^{-1}\right)$ on $60 \mathrm{DAS}$ at $125 \mathrm{ppm}$. The treatment $\mathrm{T}_{6}$ had lower level of $\mathrm{Cd}$ in grain $\left(0.0024 \mathrm{mg} \mathrm{g}^{-1}\right)$ at $125 \mathrm{ppm}$ of $\mathrm{Cd}$ and on par with $\mathrm{T}_{8}$. Dual inoculation has shown significant difference with the sole inoculation of both the organisms and can be used efficiently for bioremediation of cadmium. Inoculation of Pseudomonas and AM fungi has the ability to remove the cadmium contamination from soil and make the environment free from pollution.
\end{abstract}

Key words: Cadmium, AM fungi, glomus mosseae, pseudomonas heavy metals, germination

\section{INTRODUCTION}

Rapid industrialization, urbanization, intensive agriculture and increased contamination of heavy metals in soil is a major concern in India. "Bioremediation" is the process that uses microorganisms or their enzymes to return the natural environment altered by contaminants to its original condition. Cadmium affects root growth more severely than shoot growth (Vitoria et al., 2001). An increase in total plant or in root biomass increased the uptake of $\mathrm{Cd}$ when grown at constant $\mathrm{Cd}$ concentrations in the soil (Nylund, 2003). AM fungi Glomus mosseae and Glomus intraradices effective in accumulating heavy metals in the root system reducing metal transfer to shoots and its phytotoxic effects, contributing to the phytoremediation of contaminated soils (Whitfield et al., 2004). Hussien et al. (2001) found that various species of Pseudomonas is relatively efficient in the bioaccumulation of heavy metals than other soil rhizobacteria. The present study was undertaken with the objective to study the efficiency of AM fungi and Pseudomonas sp. on accumulation of $\mathrm{Cd}$ (II) in maize plants.

\section{MATERIALS AND METHODS}

A pot culture experiment was conducted for about one year in the green house of the Department of Agricultural Microbiology, Tamilnadu Agricultural University, Coimbatore with the standard isolates G. mosseae and P. putida. Pots $(30 \times 28 \mathrm{~cm}$ size $)$ were filled with $5 \mathrm{~kg}$ of double sterilized soil which was the mixture of red soil, sand and farmyard manure in the ratio of 2:1:1. Soil was mixed with the recommended dose of fertilizers, 300:20:200 of N:P:K mg kg${ }^{-1}$ of soil. Quarter of $\mathrm{N}$, full $\mathrm{P}$ and $\mathrm{K}$ was applied as basal and remaining $\mathrm{N}$ was applied at 45 th days after sowing.

Corresponding Author: Sivasankari Devi. T, Department of Agricultural Microbiology, UAS, GKVK, Bangalore-65, India Tel: $91(11) 09449713191$ 
Cd application: The experimental soil was spiked with $(\mathrm{Cd})$ at the rate of 75 and $125 \mathrm{mg} \mathrm{kg}^{-1}$ of soil in the form of cadmium chloride $\left(\mathrm{CdCl}_{2}\right)$. Pot mixture was incubated with desired concentrations of $\mathrm{Cd}$ for about $12 \mathrm{~h}$ before sowing.

\section{Inoculation method:}

- Pure inoculum of G. mosseae (AMs) and Glomus sp. $\left(\mathrm{AM}_{1}\right)$ were applied @ 50 g/pot (containing 8-10 spores $/ \mathrm{g}$ of inoculum) as a thin layer, $5 \mathrm{~cm}$ below the seeds prior to sowing

- Two isolates of Pseudomonas viz., $\mathrm{PS}_{1}$ and Pseudomonas putida (PSs) were used for the study. Fourty eight hours old broth cultures $\left(10^{9}\right.$ cells $\left.\mathrm{mL}^{-1}\right)$ of the selected isolates were inoculated at the rate 50 $\mathrm{mL}$ broth/pot prior to sowing

Seeds and sowing: Maize seeds (Var. CO 1) obtained from the Department of Millets, Tamil Nadu Agricultural University, Coimbatore and used for this study. The seeds were surface sterilized with $0.1 \%$ mercuric chloride for 3 minutes before sowing. The seeds were sown $3 \mathrm{~cm}$ below the surface and three plants were maintained in each pot.

Treatment details: Two factors were taken for pot culture experiment. Main factor was $\mathrm{Cd}$ concentrations and it was denoted as $\mathrm{C}_{1} ; 0 \mathrm{ppm}$ (control), $\mathrm{C}_{2} ; 75 \mathrm{ppm}$ and $\mathrm{C}_{3}, 125 \mathrm{ppm}$, and the second factor was the single and combinations of microorganisms. It was denoted as $T_{1}$ to $T_{9}$. Three replications were maintained for each treatment.

Sampling: Plant samples were collected randomly at 30th and 60th day after sowing and used for analysis. In the last sample $\mathrm{Cd}$ content in cob was also analysed.

\section{Analytical methods}

Estimation of $\mathrm{Cd}$ content in root and grain samples (USEPA, 1979): Three hundred $\mathrm{mg}$ of plant samples viz., shoot and root samples were taken in a conical flask. $10 \mathrm{~mL}$ of acid mixture of $\mathrm{HNO}_{3}$ and $\mathrm{H}_{2} \mathrm{O}_{2}(1: 1)$ was added to each sample. Then the whole content was transferred to microwave digester for digestion. The temperature was maintained at $200^{\circ} \mathrm{C}$ for $15 \mathrm{~min}$ followed by $110^{\circ} \mathrm{C}$ for 15 min and then cooled for another $15 \mathrm{~min}$. A clear solution was obtained; it was diluted with $2 \mathrm{~mL}$ of distilled water. The sample was filtered through What man No. 1 filter paper and volume was made up to $25 \mathrm{~mL}$. Readings were taken in Atomic Absorption Spectrometer (AAS).
The AM root colonization percentage and total spore count was estimated at 30 and 60 DAS in all the treatments. The AM colonization was estimated by adopting the procedure described by Phillips and Hayman (1970). AM fungal spores were collected from the rhizosphere soil samples by wet sieving and decantation technique (Gerdemann and Nicolson, 1963). Pseudomonas sp. population was estimated by serial dilution and plating. Plant samples were allowed for sun drying one day and then dried at 60 to $70^{\circ} \mathrm{C}$ and the dry biomass was obtained. The data were subjected to statistical analysis by variance $(\mathrm{p}=0.05)$ with mean separation by Least Significant Difference (LSD) as per the methods detailed by Panse and Sukhatme (1978). The analysis for microbial population count was based on the $\log$ and transformed values.

\section{RESULTS AND DISCUSSION}

Population of Pseudomonas sp.: Pseudomonas sp. population was estimated on 30 and 60 DAS of maize rhizosphere soil at different $\mathrm{Cd}$ levels. With the increased concentration of $\mathrm{Cd}$ the population was significantly reduced in all the treatments. The combined inoculation reduced the population reduction at high $\mathrm{Cd}$ level. The highest population was recorded in $\mathrm{T}_{7}$ (Glomus sp. $\left(\mathrm{AM}_{1}\right)$ with $P$. putida $\left(\mathrm{PS}_{\mathrm{S}}\right)$ ) on both 30 and 60 DAS (Table 1). Pseudomonas has the high efficiency in tolerating $\mathrm{Cd}$ contamination when inoculated with AM fungi (Katarina et al., 2004).

Estimation of AM colonization percentage and total spore count: When the maize roots were observed for AM colonization incremental levels of $\mathrm{Cd}$ reduced root colonization percentage irrespective of the treatments. Inoculation of Glomus sp. $\left(\mathrm{AM}_{1}\right)$ with Pseudomonas sp. $\left(\mathrm{PS}_{1}\right)\left(\mathrm{T}_{6}\right)$ showed highest percentage of root colonization (92\%) at $125 \mathrm{ppm}$ of $\mathrm{Cd}$ on both 30 and 60 DAS over control $\left(\mathrm{T}_{1}\right)$. The combined inoculation of AM with Pseudomonas sp. enhanced the percentage at high level of $\mathrm{Cd}$ than sole treatment (Fig. 1). The same treatment had shown the highest number of spores (109 and 139 spores $50 \mathrm{~g}^{-1}$ of soil) at $125 \mathrm{ppm}$ of $\mathrm{Cd}$ on respective 30 and 60 DAS over control $T_{1}(10$ and 15 spores $50 \mathrm{~g}^{-1}$ of soil) (Table 2). Mycorrhizal root colonization varies with heavy metals, concentrations and period of exposure. It had been shown to be delayed, reduced, and even eliminated (Liao et al., 2003). In our experiment AM colonization percentage was decreased with increasing $\mathrm{Cd}$ concentrations but had been shown 
Insight Microbiology 3(1): 9-14, 2013

Table 1: Effect of $\mathrm{Cd}$ treatment on Pseudomonas sp. population found in maize rhizosphere Pseudomonas sp. ( $\times 105 \mathrm{CFU} / \mathrm{g}$ ODS $)$

\begin{tabular}{|c|c|c|c|c|c|c|}
\hline \multirow[b]{2}{*}{ Treatments } & \multicolumn{3}{|l|}{$30 \mathrm{DAS}$} & \multicolumn{3}{|l|}{$60 \mathrm{DAS}$} \\
\hline & $\mathrm{C} 1: 0 \mathrm{ppm}$ & $\mathrm{C} 2: 75 \mathrm{ppm}$ & $\mathrm{C} 3: 125 \mathrm{ppm}$ & $\mathrm{C} 1: 0 \mathrm{ppm}$ & $\mathrm{C} 2: 75 \mathrm{ppm}$ & $\mathrm{C} 3: 125 \mathrm{ppm}$ \\
\hline T1: UI & 1.19 & 1.1 & 1.02 & 3.69 & 3.01 & 3.12 \\
\hline $\mathrm{T} 2: \mathrm{PS}_{1}$ & 4.56 & 3.71 & 2.63 & 7.06 & 6.56 & 6.16 \\
\hline T3: $\mathrm{PS}_{\mathrm{S}}$ & 4.47 & 3.1 & 2.9 & 6.36 & 6.47 & 6.73 \\
\hline $\mathrm{T} 4: \mathrm{AM}_{1}$ & 4.16 & 2.28 & 0.91 & 6.91 & 6.16 & 6.41 \\
\hline T5: $\mathrm{AM}_{\mathrm{S}}$ & 3.19 & 2.12 & 1.72 & 5.69 & 5.36 & 5.27 \\
\hline $\mathrm{T} 6: \mathrm{AM}_{1} \times \mathrm{PS}_{1}$ & 6.18 & 4.72 & 3.94 & 9.42 & 8.18 & 8.43 \\
\hline $\mathrm{T} 7: \mathrm{AM}_{1} \times \mathrm{PS}_{\mathrm{S}}$ & 6.92 & 5.1 & 4.82 & 8.68 & 8.92 & 9.69 \\
\hline T8: $\mathrm{AM}_{\mathrm{S}} \times \mathrm{PS}_{1}$ & 4.6 & 2.8 & 3.64 & 7.1 & 6.59 & 6.9 \\
\hline T9: $\mathrm{AM}_{\mathrm{S}} \times \mathrm{PS}_{\mathrm{S}}$ & 5.18 & 4.19 & 2.98 & 7.68 & 7.19 & 7.37 \\
\hline Mean & 4.49 & 3.24 & 2.73 & 6.95 & 6.49 & 6.68 \\
\hline $\mathrm{T}$ & SED & $\mathrm{CD}(0.05)$ & & SED & $\mathrm{CD}(0.05)$ & \\
\hline $\mathrm{C}$ & 0.01 & 0.02 & & 0.01 & 0.02 & \\
\hline $\mathrm{T} \times \mathrm{C}$ & 0.005 & 0.011 & & 0.005 & 0.011 & \\
\hline
\end{tabular}

Values rare mean of three replications, UI: Uninoculated control, ODS: Oven dried soil, DAS: Days after sowing, AM1: Glomus sp., AMS: Glomus mosseae, PS1: Psendomonas sp., PSS: Pseudomonas putida

Table 2: Effect of Cd treatment on AM spore count in maize rhizosphere soil

\begin{tabular}{|c|c|c|c|c|c|c|}
\hline \multirow[b]{3}{*}{ Treatments } & \multicolumn{6}{|c|}{ AM spore (No. $/ 50 \mathrm{~g}$ soil) } \\
\hline & \multicolumn{3}{|l|}{$30 \mathrm{DAS}$} & \multicolumn{3}{|l|}{$60 \mathrm{DAS}$} \\
\hline & $\mathrm{C} 1: 0 \mathrm{ppm}$ & $\mathrm{C} 2: 75 \mathrm{ppm}$ & $\mathrm{C} 3: 125 \mathrm{ppm}$ & $\mathrm{C} 1: 0 \mathrm{ppm}$ & $\mathrm{C} 2: 75 \mathrm{ppm}$ & $\mathrm{C} 3: 125 \mathrm{ppm}$ \\
\hline T1: UI & 20 & 13 & 10 & 26 & 22 & 15 \\
\hline $\mathrm{T} 2: \mathrm{PS}_{1}$ & 23 & 18 & 15 & 35 & 22 & 15 \\
\hline T3: $\mathrm{PS}_{\mathrm{S}}$ & 25 & 21 & 18 & 40 & 33 & 28 \\
\hline T4: $\mathrm{AM}_{1}$ & 95 & 56 & 49 & 110 & 86 & 79 \\
\hline T5: $\mathrm{AM}_{\mathrm{S}}$ & 80 & 80 & 67 & 125 & 110 & 97 \\
\hline T6: $\mathrm{AM}_{1} \times \mathrm{PS}_{1}$ & 118 & 117 & 109 & 163 & 147 & 139 \\
\hline $\mathrm{T} 7: \mathrm{AM}_{1} \times \mathrm{PS}_{\mathrm{S}}$ & 114 & 115 & 90 & 159 & 145 & 120 \\
\hline T8: $\mathrm{AM}_{\mathrm{S}} \times \mathrm{PS}_{1}$ & 100 & 98 & 85 & 145 & 128 & 115 \\
\hline $\mathrm{T} 9: \mathrm{AM}_{\mathrm{S}} \times \mathrm{PS}_{\mathrm{S}}$ & 104 & 105 & 92 & 149 & 135 & 122 \\
\hline Mean & 75.44 & 69.22 & 59.44 & 105.78 & 92 & 81.11 \\
\hline $\mathrm{T}$ & SED & $\mathrm{CD}(0.05)$ & & SED & $\mathrm{CD}(0.05)$ & \\
\hline $\mathrm{C}$ & 1.847 & 3.704 & & 2.5 & 5.012 & \\
\hline $\mathrm{T} \times \mathrm{C}$ & 1.066 & 2.138 & & 1.443 & 2.894 & \\
\hline
\end{tabular}

Values rare mean of three replications, UI: Uninoculated control, ODS: Oven dried soil, DAS: Days after sowing, AM1: Glomus sp., AMS: Glomus mosseae, PS1: Psendomonas sp., PSS: Psendomonas putida

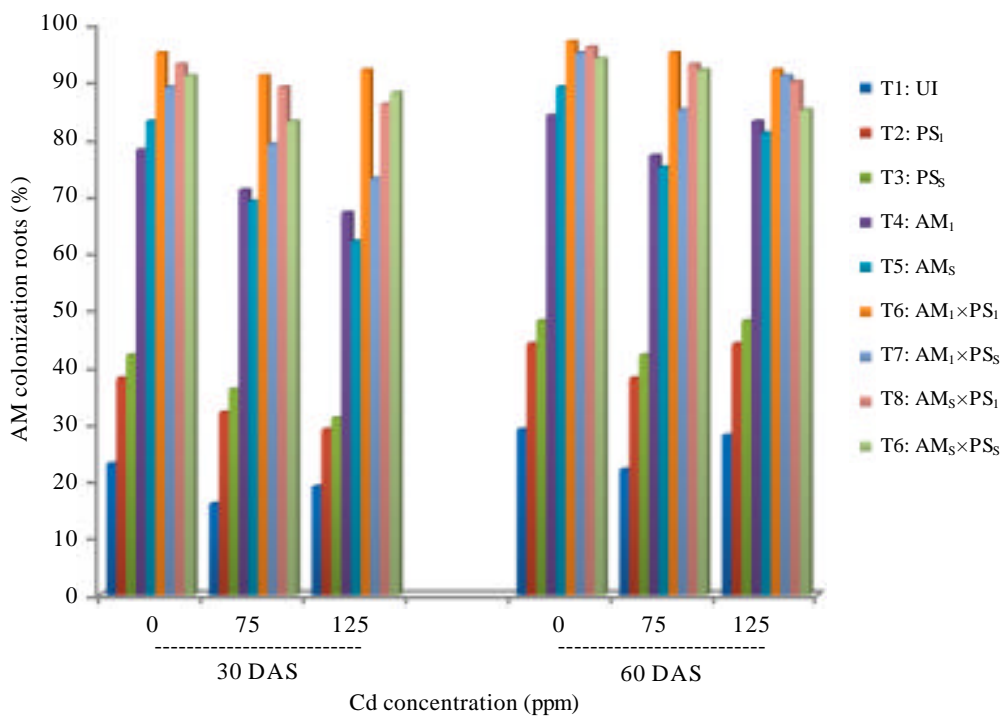

Fig. 1: Effect of Cd on AM colonization in maize plant 
that this percentage was increased on 60 DAS when compared to 30 DAS. Our results are in agreement with those obtained by Tullio et al. (2003) who reported that the mycorrhizal infection percentage and the spore numbers are decreased by increasing the $\mathrm{Cd}$ content of soil. Spore density was also reduced with increasing Cd levels but it had been shown that the spore density was increased on 60DAS over 30 DAS. But Khan et al. (2000) found that there was no adverse effect of heavy metal on spore numbers and AM colonization of maize.

Dry biomass of maize plantsL: The oven dried plants were weighed on 30 and 60 DAS. It was observed that the dry weight of the plants was reduced with increased levels of $\mathrm{Cd}$ in all the treatments on 30 DAS. The treatment $\left(\mathrm{T}_{6}\right)$ had shown increased dry biomass of 23.75 $\left(\mathrm{g} \mathrm{pL}^{-1}\right.$ ) and it is on par with $\mathrm{T}_{8}$ (Fig. 2). Cd stress causes significant decrease in fresh weight, dry weight, root length and shoot length (Malekzadeh et al., 2007). At higher concentration of $\mathrm{Cd}$ mycorhizal plants showed increased shoot and root weight than non-mycorhizal plants (Liao et al., 2003). In contrast to this, in the present study dry weight of the plant was decreased with increased levels of $\mathrm{Cd}$. This may be due to the inhibition of root cell division or root elongation due to $\mathrm{Cd}$ toxicity. Heavy metal stress surely affects the plant growth, but the inoculation of AM fungi with Pseudomonas sp. in $\mathrm{Cd}$ contaminated areas there was less reduction in the overall plant growth. It agreed with the results of Lin et al. (2007), who reported that increased levels of $\mathrm{Cd}$ increased fresh weight and dry weight of wheat plants.

Cd content in root and grain of maize plant: The amount of applied $\mathrm{Cd}$ translocated in to the maize plant system was analyzed separately for root and grain. The $\mathrm{Cd}$ content in roots had increased with increasing levels of $\mathrm{Cd}$ in all the treatments. There was increase in the accumulation of $\mathrm{Cd}$ in roots on 60 DAS compared to 30 DAS. The treatment $\mathrm{T}_{8}$ (G. mosseae (AMs) with Pseudomonas sp. $\left(\mathrm{PS}_{1}\right)$ ) had accumulated high level of $\mathrm{Cd}$ in roots (3.1856 $\mathrm{mg} \mathrm{g}^{-1}$ ) on 60 DAS at 125 ppm (Fig. 3). The treatment $\mathrm{T}_{6}$ had lower level of $\mathrm{Cd}$ in grain $\left(0.0024 \mathrm{mg} \mathrm{g}^{-1}\right)$ at $125 \mathrm{ppm}$ of $\mathrm{Cd}$ and on par with $\mathrm{T}_{8}$ (Fig. 4). The combined inoculation of AM fungi with Pseudomonas sp. increased the root $\mathrm{Cd}$ accumulation. Latif (2008) had reported increased accumulation of $\mathrm{Cd}$ in root than shoot and this accumulation has increased with long duration of exposure. In mycorrhizal plants the accumulation of metal was more in roots but the transfer of metal from root to shoot was restricted (Chen et al., 2004). Mycorrhizal colonization may alter the morphological and physiological changes in the roots (Atkinson et al., 1994), with subsequent modifications in the mycorrhizosphere and this influenced the metal mobility and uptake by the plants at elevated levels of soil $\mathrm{pH}$. Metal concentration in maize grains was increased with increasing Cd levels, but in treatments with both AM and Pseudomonas the concentration of metal in grain was reduced. Reduced translocation of

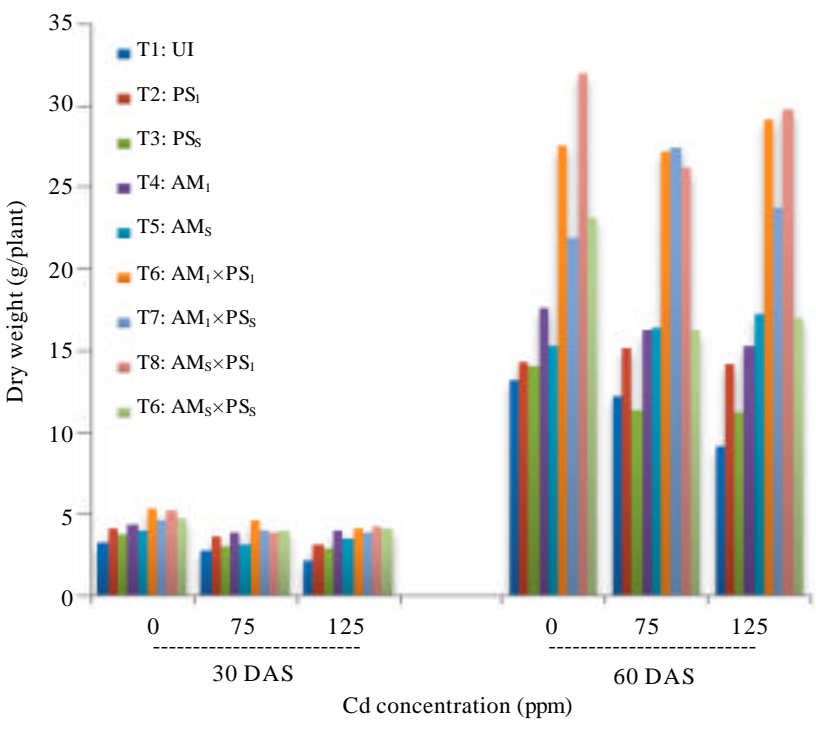

Fig. 2: Effect of Cd on dry biomass of maize plant 


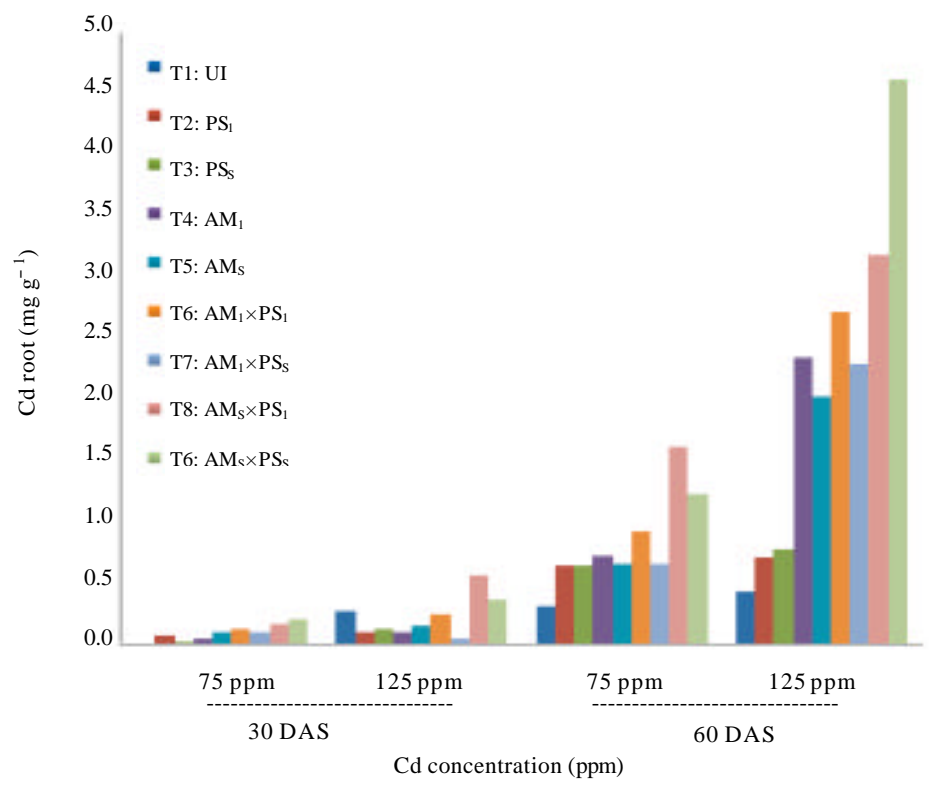

Fig. 3: $\mathrm{Cd}$ accumulation in maize root

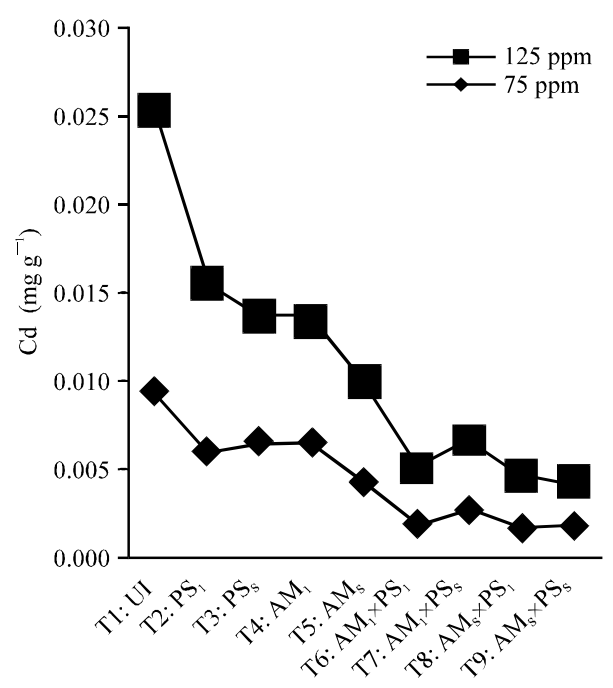

Fig. 4: Cd accumulation in maize grain

metal to the grains was observed in AM colonized plants as they restrict the transfer of metal from root to shoot and grain.

\section{CONCLUSION}

Based on the results discussed above cadmium toxicity in plants as well as in soil was reduced by the inoculation of AM fungi with Pseudomonas sp. The phytochemical changes in the plant facilitate the accumulation of $\mathrm{Cd}$ in the roots and reduced the translocation of $\mathrm{Cd}$ to shoots and economic parts. It can be concluded that consortium of microorganisms can be utilized for the bioremediation of $\mathrm{Cd}$ contaminated soil in a cost effective manner.

\section{REFERENCES}

Atkinson, D., G. Berta and J.E. Hooker, 1994. Impact of Mycorrhizal Colonization on Root Architecture, Root Longevity and the Formation of Growth Regulators. In: Impact of Arbuscular Mycorrhizas on Sustainable Agriculture and Natural Ecosystems. Gianinazzi, S. and H. Schuepp (Eds.)., Birkhauser, Basel, pp: 89-99.

Chen, B.D., Y. Liu, H. Shen, X.L. Li and P. Christie, 2004. Uptake of cadmium from an experimentally contaminated calcareous soil by arbuscular mycorrhizal maize (Zea mays L.). Mycorrhiza, 14: 347-354.

Gerdemann, J.W. and T.H. Nicolson, 1963. Spores of mycorrhizal endogone species extracted from soil by wet sieving and decanting. Trans. Br. Mycol. Soc., 46: $235-244$.

Hussien, H., R. Krull, S.I.A. El-Ela and D.C. Hempel, 2001. Interaction of the different heavy metal ions with immobilized bacterial cultured degrading xenobiotic waste water compounds. Proceedings of the International Water Association World Water Conference, October 15-19, 2001, Berlin Germany. 
Katarina, C., S. Darina, K. Vladimir, P. Miloslava and H. Jana et al., 2004. Identification and characterization of eight cadmium resistant bacterial isolates from a cadmium-contaminated sewage sludge. Biol. Bratislava, 59: 817-827.

Khan, A.G., C. Kuek, T.M. Chaudhry, C.S. Khoo and W.J. Hayes, 2000. Role of plants, mycorrhizae and phytochelators in heavy metal contaminated land remediation. Chemosphere, 41: 197-207.

Latif, A.A., 2008. Cadmium induced changes in pigment content, ion uptake, proline content and phosphoenolpyruvate carboxylase activity in Triticum aestivum seedlings. Austr. J. Basic Applied Sci., 2: 57-62.

Liao, J.P., X.G. Lin, Z.H. Cao, V.Q. Shi and M.H. Wong, 2003. Interactions between arbuscular mycorrhizae and heavy metals un- der sand culture experiment. Chemosphere, 50: 847-853.

Lin, A.J., X.H. Zhang, M.H. Wong, Z.H. Ye, L.Q. Lou, Y.S. Wang and Y.G. Zhu, 2007. Increase of multimetal tolerance of three leguminous plants by arbuscular mycorrhizal fungi colonization. Environ. Geochem. Health, 29: 473-481.

Malekzadeh, P., J. Khara, S. Farshian, A.K. Jamal-Abad and $\mathrm{S}$. Rahmatzadeh, 2007. Cadmium toxicity in maize seedlings: Changes in antioxidant enzyme activities and root growth. Pak. J. Biol. Sci., 10: 127-131.

Nylund, E., 2003. Cadmium uptake in willow (Salix viminalis L.) and spring wheat (Triticum aestivum L.) in relation to plant growth and $\mathrm{Cd}$ concentration in soil solution. M.Sc. Thesis, Department of Soil Sciences, Division of Environmental Physics, Swedish University of Agricultural Sciences.
Panse, V.G. and P.V. Sukhatme, 1978. Statistical Methods for Agricultural Workers. Indian Council of Agricultural Research, New Delhi, Pages: 347.

Phillips, J.M. and D.S. Hayman, 1970. Improved procedures for clearing roots and staining parasitic and vesicular-arbuscular mycorrhizal fungi for rapid assessment of infection. Trans. Br. Mycol. Soc., 55: 158-161.

Tullio, M., F. Pierandrei, A. Salemo and E. Rea, 2003. Tolerance to cadmium of vesicular arbuscular mycorrhizae spores isolated from a cadmium-polluted and unpolluted soil. Biol. Fertil. Soils, 37: 211-214.

USEPA, 1979. Method 218.1. Atomic absorption direct aspiration. Methods for Chemical Analysis of Water and Wastes, EPA-600/4-79-020, US, EPA, Environmental Monitoring and Support Laboratory, Cincinnati, $\mathrm{OH}$.

Vitoria, A.P., P.J. Lea and R.A. Azevedo, 2001. Antioxidant enzymes responses to cadmium in radish tissues. Phytochem., 57: 701-710.

Whitfield, L., A. Richards and D. Rimmer, 2004. Relationships between soil heavy metal concentration and mycorrhizal colonisation in Thymus polytrichus in northern England. Mycorrhiza, 14: 55-62. 